\title{
RELATIONSHIP OF ARM STRENGTH TO TABLE TENNIS FOREHAND DRIVE SKILLS AT THE PTMSI CLUB BENGKULU CITY
}

\author{
*Edho Pranata, Tito Parta Wibowo \\ Correspondence: Dehasen of Bengkulu University \\ E-mail: edhopranata20@gmail.com
}

\begin{abstract}
The purpose of this study was to determine whether there is a relationship between arm muscle strength and forehand drive skills in table tennis. This study uses a correlational research method. Subjects or samples in this study were PTMSI athletes in Bengkulu, totaling 20 people. The instruments used in this study were a questionnaire, a questionnaire, as well as an arm muscle strength test instrument and a forehand drive skill test instrument used to collect data. The stages in this study are: (1) Conducting observations, (2) distributing questionnaires and questionnaires, and (3) testing instruments for arm muscle strength and forehand drive skills. As for the value obtained $r$ count $0.65>r$ table 0.468. Based on the data obtained, it can be concluded that there is a significant relationship between arm muscle strength and forehand drive skills in table tennis.
\end{abstract}

Keywords: Arm Muscle Strength, Forehand Drive, Table Tennis.

\section{Introduction}

The drive stroke is a primary stroke that every table tennis athlete must master. This punch is one of the most effective punching techniques in the development of other punching techniques. This is because the drive stroke is the basis of other punching teenniques! such as smashest, spins, and others. tin athlete with a good drive will usually also affect his smash and spin shots for the better. This is possible because the basic movements are almost the same and only differ in the ending and the amount of energy expended.

Based on the observations made by the author, currently, most beginners are more interested in directly learning advanced techniques such as smashes, spin punches, and others without learning basic techniques first, such as the drive stroke of them. This is because most of them have many reasons to want to be able to quickly become proficient at playing table tennis, which is a mistake by learning advanced techniques without knowing the basic techniques first. 


\section{Theoretical Framework}

\section{Forehand Drive}

According to David Apriyanto (2012: 69), "drive is a blow with a long swing so as to produce a flat and hard hit". The correct drive stroke is when doing it spins the ball produced little or no spin. Ika Rudi Mahendra et al. (2012: 12) said, "forehand strokes are the most powerful strokes, besides the power used is usually more leverage than backhand strokes". This is because the arm's reach when making forehand strokes is broader and longer than when doing backhand strokes, which will greatly affect the amount of energy that can be issued.

According to Sutarmin (2007: 21), "when hitting the ball, the position of the palm of the hand holding the bet / racket is facing forward". Meanwhile, according to Teguh Santosa (2016: 35), "Forehand is a stroke made to the right of the player". Based on the description above, it can be concluded that the forehand drive is a shot made with a long and hard swing when the ball is on the right side of the body so that it produces a flat and hard hit. According to Anne Nelistya (2011: 33), the correct way to do a forehand drive is as follows:

- The left foot is in front, and the body is sideways.

- The arms are at the sides of the body.

- Upper arms and body form a $45^{\circ}$ angle.

- The forearm and upper arm form a $90^{\circ}$ angle.

- Elbows are pushed forward.

- When making a stroke, bet in a closed position.

- The bet is swung from back to front and from top to bottom.

\section{Arm Muscle Strength}

According to Bompa (2009: 261), "strength can also be interpreted as the ability of the neuromuscular system to produce energy against external resistance". Meanwhile, according to Bayu Rahadian et al. (2008: 60), "Physiologically, muscle strength is the ability of a muscle or a group of muscles to perform one maximal contraction against resistance or load". Based on this, it can be understood that the arm muscles are the muscles in the arm that contract quickly and powerfully in order to produce great force.

Anatomically, a person's arm muscles will produce great strength if they can contract maximally, both when lengthening and shortening in a relatively short time. In doing forehand drive strokes, arm muscle strength is essential to perform maximum forehand drive strokes. This is directly proportional to the drive stroke's purpose to produce a flat and hard hit.

\section{Method}

PJKR_

https://jurnal.unimed.ac.id/2012/index.php/jpehr 
The type of research conducted is correlational research used to determine the relationship between the variables and aims to see whether there is a correlation between the independent and dependent variables. The independent variable is arm muscle strength, and the dependent variable is forehand drive.

The population in this study were PTMSI athletes in Bengkulu city, and the samples taken were 20 people. The model in this study was born with a saturated sampling technique. The data types in this study are primary data obtained from direct tests in the field and secondary data taken from club documentation. The data sources in this study were obtained from coaches and the management of the PTMSI club in Bengkulu city. The instrument used to collect data is a direct test in the field with an examination of arm muscle strength and forehand drive skills. The data were analyzed using the product-moment correlation formula.

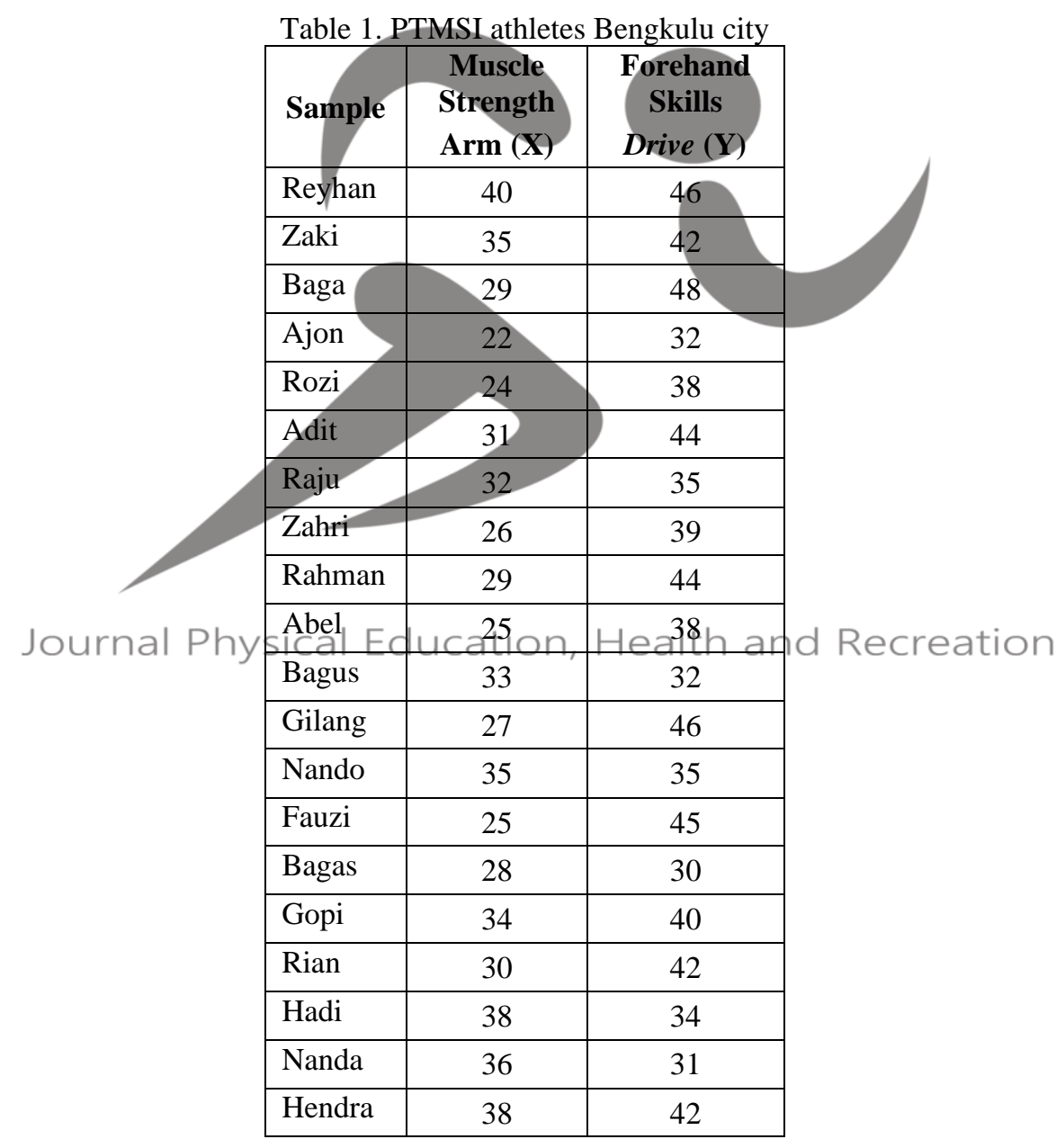

PJKR

https://jurnal.unimed.ac.id/2012/index.php/jpehr 


\section{Data analysis}

Normality test

\begin{tabular}{|c|c|c|c|c|}
\hline Variable & $\mathbf{n}$ & Lo & L table & Information \\
\hline $\begin{array}{c}\text { Arm Muscle } \\
\text { Strength (X) }\end{array}$ & 20 & 0,0906 & 0,190 & Normal \\
\hline $\begin{array}{c}\text { Forehand } \\
\text { Drive (Y) }\end{array}$ & 20 & 0,1204 & 0,190 & Normal \\
\hline
\end{tabular}

Based on the description above, all data collected on each research variable is normally distributed. This means that the data is normally distributed so that it can be used in subsequent tests.

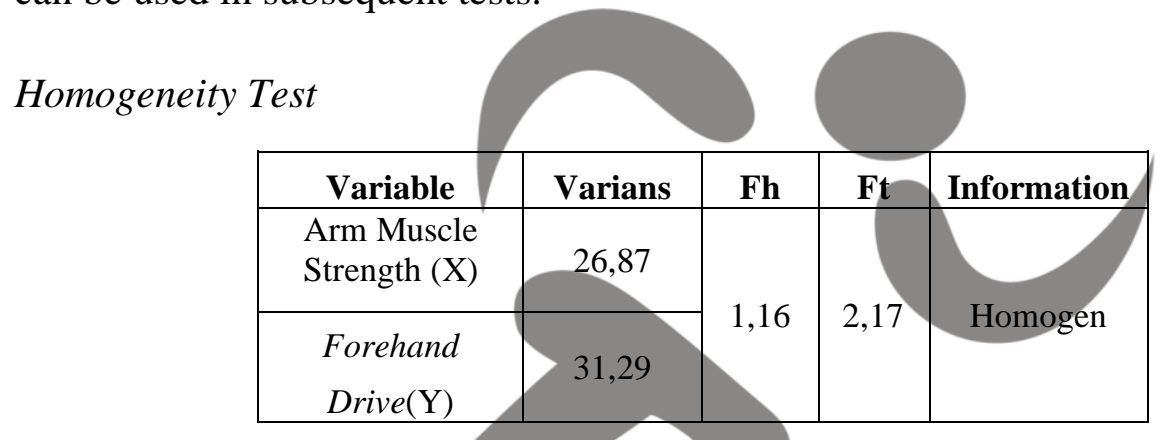

Based on the description above, it can be seen that the data in this study have the same variance (homogeneous), so it can be continued for hypothesis testing.

Journal Physical Education, Health and Recreation Hypothesis test

$$
r x y=\frac{N \sum X Y-\left(\sum X\right)\left(\sum Y\right)}{\left.\left.\sqrt{\left\{N \sum X^{2}\right.}-\left(\sum X\right)^{2}\right\} N \sum Y^{2}-\left(\sum Y\right)^{2}\right\}}
$$

The analysis results show that arm muscle strength (X) has a significant relationship with forehand drive skills (Y). In the correlation analysis table, the correlation coefficient of arm muscle strength with forehand drive skills is worth (rxy) $=$ rcount $0.65>$ rtable 0.468 , which means the relationship between the two variables is powerful and unidirectional. Thus it is proven that the correlation coefficient implies that the proposed hypothesis is accepted.

\section{Discussion}

PJKR_

https://jurnal.unimed.ac.id/2012/index.php/jpehr 
Based on the research results at the PTMSI club in Bengkulu city to see the relationship between arm muscle strength and forehand drive in table tennis, there is a significant relationship between the two variables. The acceptance of the hypothesis, which states that there is a substantial relationship between arm muscle strength and forehand drive in table tennis games for PTMSI athletes in Bengkulu city, results in rcount $0.65>$ rtable 0.468 . However, before carrying out the data analysis test, the normality test and homogeneity test were first carried out as a condition for conducting a data analysis test or a hypothesis test. The results of the data were normally distributed and homogeneous. So it can be concluded that there is a significant relationship between arm muscle strength and forehand drive.

The efforts that can be made by the coach to produce table tennis athletes who excel are to start training these athletes from an early age. Every club should regularly hold table tennis matches every month. This can also motivate athletes to introduce even more challenges to achieve the desired performance. It is hoped that in the future, table tennis will be more developed and better known to the world through talented and accomplished young athletes.

\section{Result}

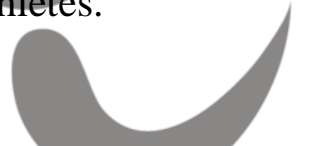

Based on the research results at the PTMSI club in Bengkulu city to see the relationship between arm muscle strength and forehand drive in table tennis, there is a significant relationship between the two variables. The acceptance of the hypothesis, which states that there is a substantial relationship between arm muscle strength and forehand drive in table tennis games for PTMSI athletes in Bengkulu city, results in rcount $0.65>$ rtable 0.468 . However, before carrying out the data analysis test, the normality test and homogeneity test were first carried out as a eondition for/eonducting a data analysis ltest or a hypothesis test. The results of the data were normally distributed and homogeneous. So it can be concluded that there is a significant relationship between arm muscle strength and forehand drive.

The efforts that can be made by the coach to produce table tennis athletes who excel are to start training these athletes from an early age. Every club should regularly hold table tennis matches every month. This can also motivate athletes to introduce even more challenges to achieve the desired performance. It is hoped that in the future, table tennis will be more developed and better known to the world through talented and accomplished young athletes.

Based on the research results at the PTMSI club in Bengkulu city to see the relationship between arm muscle strength and forehand drive in table tennis, there is a significant relationship between the two variables. The acceptance of the 
hypothesis, which states that there is a substantial relationship between arm muscle strength and forehand drive in table tennis games for PTMSI athletes in Bengkulu city, results in rcount $0.65>$ rtable 0.468 . However, before carrying out the data analysis test, the normality test and homogeneity test were first carried out as a condition for conducting a data analysis test or a hypothesis test. The results of the data were normally distributed and homogeneous. So it can be concluded that there is a significant relationship between arm muscle strength and forehand drive.

The efforts that can be made by the coach to produce table tennis athletes who excel are to start training these athletes from an early age. Every club should regularly hold table tennis matches every month. This can also motivate athletes to introduce even more challenges to achieve the desired performance. It is hoped that in the future, table tennis will be more developed and better known to the world through talented and accomplished young athletes.

\section{References}

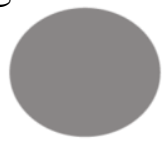

Bayu Rahadian (dkk). Pedoman Biomekanika dan Kebugaran Jasmani. Jakarta: Kemenpora, 2008).

David Apriyanto. Mengenal Tenis Meja. Jakarta Timur: Balai Pustaka, 2012.

Ika Rudi Mahendra, Prapto Nugroho, dan Said Junaidi. Kelentukan Pergelangan Tangan dan Koordinasi Mata Tangan dalam Pukulan Forehand Tenis Meja. Journal of Sport Sciences and Fitness, Vol. 1 (1), 2012.

Nelistya, Anne. Menjadi Juara Tenis Meja. Jakarta: Be Champion, 2011.

Teguh Santosa. Pengembangan Alat Bantu Return Board untuk Forehand Topspin Tenis Meja Jurnat Pedagogik Keolahragaan,tKol, 22 (2)R2016ation

Tudor O. Bompa dan G. Gregory Haff. Theory and Methodology of Training US: Human Kinetics, 2009.

Sutarmin. Terampil Berolahraga Tenis Meja. Surakarta: Era Intermedia, 2007. 